\title{
Analisis Penguasaan Konsep pada Tekanan Hidrostatis dan Hukum Pascal Mahasiswa Pendidikan Fisika
}

\author{
S. Indana Zulfa*, Ainun Nikmah and E. Khoirun Nisak
}

\begin{abstract}
Ringkasan
Penelitian ini bertujuan untuk mengetahui tingkat penguasaan konsep pada materi tekanan hidrostatis dan hukum pascal. Penelitian ini menggunakan metode deskriptif dengan teknik sampling berupa purposive sampling (sample dengan tujuan tertentu). Terdapat 19 soal penguasaan konsep dengan 10 soal pilihan ganda beralasan dan 9 soal pernyataan benar atau salah disertai alasan. Soal-soal penguasaan konsep tersebut disebar ke 109 mahasiswa pendidikan fisika angkatan 2018 dan 2019. Berdasarkan analisis data, kesulitan mahasiswa terletak pada pengaplikasian persamaan dan penguasaan prinsip-prinsip yang bekerja pada tekanan hidrostatis. Mahasiswa hanya memahami bahwa suatu objek yang memiliki kedalam yang sama, juga memiliki tekanan yang sama. Namun sayangnya, syarat dari keadaan tersebut diabaikan. Lebih lanjut, mahasiswa juga mengalami kesulitan untuk menentukan gaya-gaya yang bekerja di dalam bejana. Hal ini diketahui berdasarkan jawaban dari soal soal penguasaan konsep. Dimana $12 \%$ dari mahasiswa tidak mampu menjawab dan memberikan alasan yang tepat. Sedangkan $88 \%$ sisanya memberi jawaban yang salah.
\end{abstract}

Kata Kunci : penguasaan konsep, hukum pascal, tekanan hidrostatis.

\begin{abstract}
This study aims to know the concepts mastery levels of hydrostatic pressure materials and pascal's laws. Well, the research uses a descriptive method by sampling technique (which is arguably sampling). There are 19 doctrinal mastery issues with 10 questions of multiple rationale choices and 9 questions of statement true or false with reason. The concept mastery issues were spread to 109 students of class, 2018 and 2019 physics classes. Based on data analysis, student difficulties lie in application of equations and mastery principles that work on hydrostatic pressure. Students only understand that objects that have the same inward, also have the same pressures. But unfortunately, the conditions of the situation were ignored. Furthermore, students also have difficulty determining the forces that work inside vessels. This is known based on the answer to the question of concept mastery. Where $12 \%$ of the students are unable to answer and provide the right reasons. Whereas the remaining $88 \%$ gave the wrong answer.
\end{abstract}

Keywords: conceptual mastery; pascal's law; hydrostatic pressure.

\section{PENDAHULUAN}

Fisika merupakan salah satu ilmu pengetahuan yang membutuhkan pemahaman konsep yang cukup dalam. Praktiknya, fisika akan lebih mudah jika konsep-kosep dasar yang terkait dengan materi fisika dipahami dan dikuasai. Tujuan dari hakikat pembelajaran

\footnotetext{
${ }^{*}$ Correspondence: salsabilazulfa.1703216@students.um.ac.id Jurusan Fisika, Fakultas Matematika dan Ilmu Pengetahuan Alam, Universitas Negeri Malang, Jl. Cakrawala No. 5, Sumbersari, Lowokwaru, Kota Malang, Jawa Timur, Indonesia

Full list of author information is available at the end of the article

${ }^{\dagger}$ Equal contributor
}

fisika adalah untuk mengantarkan pemahaman peserta didik menguasai konsep-konsep dan keterkaitannya untuk dapat memecahkan masalah terkait dalam kehidupan sehari-hari [1][2]. Salah satu materi fisika yang memerlukan penguasaan konsep yang baik dan benar ialah materi fluida statis [3], khususnya pada tekanan hidrostatis [4][5].

Pembahasan fluida statis ini erat kaitannya dengan aktivitas kehidupan sehari-hari. Fluida statis membahas mengenai tekanan hidrostatis, hukum pascal, dan hukum archimedes [6][3][7][8]. Dimana pada hukum pascal terdapat pengetahuan 
dasar mengenai tekanan hidrostatis. Penelitian yang dilakukan oleh Widodo [9] membuktikan bahwa peserta didik mengalami kesulitan memahami fenomena yang ada di kehidupan sehari-hari yang merupakan fenomena fluida statis. Selain itu, dalam penelitian yang dilakukan oleh Prastiwi [10] didapati bahwa pemahaman konsep peserta didik tergolong rendah, yakni berada di skor sebesar 3,15 dari skor maksimum 10. Dari kedua penelitian ini menyebutkan bahwa peserta didik kesulitan memahami prinsip dari tekanan hidrostatis [10][9].

Tekanan hidrostatis adalah tekanan yang diakibatkan oleh gaya yang ada pada zat cair terhadap suatu luas bidang tekanan pada kedalaman tertentu [6][7]. Secara konseptual tekanan hidrostatis terjadi atas dasar hukum pascal. Konsep penting yang perlu dipahami dalam materi fluida statis, khususnya tekanan hidrostatis ialah tekanan hidrostatis tidak dipengaruhi oleh massa jenis wadah, melainkan dipengaruhi oleh massa jenis zat cair, udara di sekeliling, percepatan gravitasi dan kedalaman dari benda yang berada di dalam zat cair tersebut, konsep penting yang perlu dipahami juga ialah prinsip-prinsip dari hukumm pascal [6][11][3]. Peserta didik menganggap tekanan hidrostatis pada bejana tertutup lebih besar dibandingkan dengan bejana yang tidak tertutup. Tidak hanya peserta didik yang berada di SMA saja, melainkan mahasiswa calon pendidik fisika pun kerapkali kurang menguasai konsep dari fluida statis, khususnya tekanan hidrostatis [12].

Sebelumnya telah dilakukan penelitian mengenai miskonsepsi fluida statis pada mahasiswa pendidikan fisika Universitas Samudra [12], namun belum ditemukan penelitian yang membahas mengenai penguasaan konsep tekanan hidrostatis dan hukum pascal secara spesifik kepada mahasiswa. Oleh karena itu, penelitian kali ini difokuskan pada penguasaan konsep mahasiswa pendidikan fisika mengenai materi tekanan hidrostatis dan hukum pascal. Penelitian ini bertujuan untuk mengeksplorasi penguasaan konsep mahasiswa mengenai materi tekanan hidrostatis dan hukum pascal agar dapat teridentifikasi kesulitan yang dialami mahasiswa.

\section{METODE PENELITIAN}

Penelitian ini menggunakan metode deskriptif dengan teknik sampling yang digunakan dalam penelitian ini adalah purposive sampling (sampel dengan tujuan tertentu). Data yang digunakan adalah data hasil tes penguasaan konsep pada materi tekanan hidrostatis dan hukum pascal dengan populasi pada penleitian ini adalah mahasiswa pendidikan fisika semester 1-3 angkatan 2019 dan 2018 dengan jumlah mahasiswa sebanyak 109 orang yang tengah menempuh maupun telah menempuh mata kuliah fisika dasar I. Adapun 109 orang mahasiswa itu tersebar di lima offering, yaitu: offering ac angkatan 2019 yang beranggotakan 22 orang mahasiswa, offering b angkatan 2019 yang beranggotakan 24 orang mahasiswa, offering c angkatan 2019 yang beranggotakan 24 orang mahasiswa, offering d angkatan 2019 yang beranggotakan 23 orang mahasiswa, dan offering ac angkatan 2018 yang beranggotakan 20 orang mahasiswa.

Tes penguasaan konsep yang diberikan terdiri dari 10 soal pilihan ganda dan 9 soal meganalisa pernyataan dengan jawaban benar dan salah serta dilengkapi dengan alasan yang difokuskan pada prinsip-prinsip yang bekerja pada tekanan hidrostatis dan hukum pascal ini diadaptasi dari [13]. Pemberian tes penguasaan konsep tersebut bertujuan untuk mengukur penguasaan konsep mahasiswa dan mengetahui kesalahan-kesalahan umum mahasiswa dalam menjawab soal-soal tersebut.

Hasil jawaban yang telah dikoreksi diberi satu poin dan jika salah tidak diberi poin atau poin nol. Jawaban yang salah dianalisis untuk mengetahui kesalahan yang dibuat oleh mahasiswa dalam memahami soal-soal terkait penguasaan konsep materi tekanan hidrostatis dan hukum pascal.

\section{HASIL DAN PEMBAHASAN}

Analisis hasil jawaban mahasiswa berupa 10 soal pilihan ganda dan 9 soal meganalisa pernyataan dengan jawaban benar dan salah serta dilengkapi dengan alasan yang dikemukakan oleh mahasiswa ini menggunakan persentase. Persentase kesalahan jawaban mahasiswa ini bertujuan untuk mengetahui kesulitan-kesulitan yang dialami mahasiswa dalam menyelesaikan soal-soal yang telah diberikan. Pada penelitian ini didapatkan kesalahan yang dialami mahasiswa terlihat pada soal-soal yang membahas mengenai tekanan hidrostatis, sedangkan untuk soal-soal hukum pascal didapatkan hasil jawaban mahasiswa memiliki jawaban dan alasan yang sesuai dengan konsep. Pada penelitian ini didapatkan kesulitan mahasiswa dalam mengerjakan soal-soal nomor $1,5,7,10$, dan 13 terbukti dengan kesalahan jawaban mahasiswa di bawah 32\%, sedangkan untuk nomor $2,3,4,6,8,9,11,12,14,15$, $16,17,18$, dan 19 mahasiswa dapat menjawab dengan benar dan memberikan alasan jawaban dengan benar dengan persentase diatas $32 \%$. Secara keseluruhan perbandingan penguasaan konsep mahasiswa berdasarkan persentase jawaban benar didapatkan data hasil jawaban mahasiswa dengan grafik yang ditunjukkan pada Gambar 1. Kami sajikan rincian sebaran jawaban dan persentase kesalahan 
mahasiswa pada soal nomor $1,5,7,10$, dan 13 pada Tabel 1.

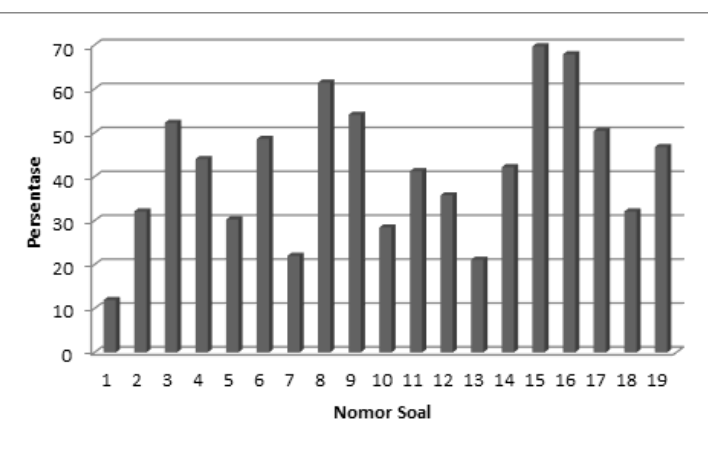

Gambar 1: Perbandingan penguasaan konsep mahasiswa berdasarkan persentase jawaban benar didapatkan data hasil jawaban mahasiswa

Tabel 1: Sebaran dan Persentase Jawaban Mahasiswa pada Soal Nomor 1, 5, 7, 10, dan 13

\begin{tabular}{|c|c|c|c|c|c|c|}
\hline \multirow{2}{*}{ Soal } & \multicolumn{5}{|c|}{ Pilihan Jawaban } & \multirow{2}{*}{$\begin{array}{c}\text { Persentase } \\
\text { Jawaban Benar }\end{array}$} \\
\hline & A & B & $\mathrm{C}$ & $\mathrm{D}$ & $E$ & \\
\hline 1 & 13 & 46 & 50 & - & - & $12 \%$ \\
\hline 5 & 34 & 13 & 8 & 33 & 21 & $30,3 \%$ \\
\hline 7 & 18 & 24 & 33 & 4 & 30 & $22 \%$ \\
\hline \multirow{2}{*}{ Soal } & \multicolumn{5}{|c|}{ Pilihan Jawaban } & Persentase \\
\hline & \multicolumn{2}{|c|}{ Benar } & Salah & \multicolumn{2}{|c|}{ Kosong } & Jawaban Benar \\
\hline 10 & \multicolumn{2}{|c|}{31} & 44 & \multicolumn{2}{|c|}{34} & $28,4 \%$ \\
\hline 13 & \multicolumn{2}{|c|}{23} & 80 & \multicolumn{2}{|c|}{6} & $21,1 \%$ \\
\hline
\end{tabular}

Berikut adalah pemaparan mengenai kesalahan yang paling banyak dialami oleh mahasiswa pada nomor $1,5,7,10$, dan 13 .

\section{Soal Nomor 1}

Pada soal penguasaan konsep pertama mengenai prinsip tekanan hidrostatis membahas mengenai gaya tekan pada alas sebuah bejana. Adapun uraian soalnya ditunjukkan pada Gambar 2. Persentase jawaban mahasiswa dan alasan yang dikemukakan mahasiswa pada soal nomor 1 ditunjukkan pada Tabel 2.

Tabel 2: Persentase jawaban mahasiswa pada soal nomor 1

\begin{tabular}{|l|l|}
\hline \multicolumn{1}{|c|}{ Pilihan jawaban } & Persentase \\
\hline a. Lebih kecil dari berat air secara keseluruhan & $12 \%$ \\
\hline b. Sama dengan berat air secara keseluruhan & $42,2 \%$ \\
\hline c. Lebih besar dari berat air secara keseluruhan & $45,8 \%$ \\
\hline
\end{tabular}

Berdasarkan analisis data pada Tabel 2 tersebut didapatkan bahwa persentase mahasiswa yang menjawab dengan jawaban dan alasan yang tepat sebanyak $12 \%$. Pilihan jawaban a benar dikarenakan tidak semua cairan menekan alas bejana. Hal ini
Sebuah bejana yang diisi dengan air, gaya tekan (pada arah tegak lurus) yang dikerjakan oleh air pada alas bejana adalah.....

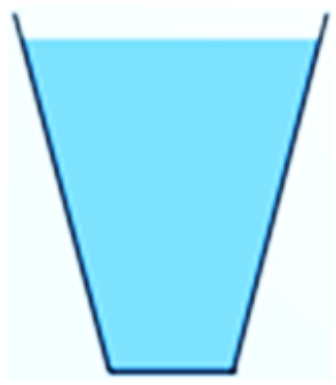

Gambar 2: Gambar soal konsep nomor 1

disebabkan oleh gaya yang bekerja pada alas bejana hanya gaya berat air yang tepat berada di atas alas bejana. Fluida yang bagian samping memberikan gaya (pada arah tegak lurus) pada dinding samping bejana. Sebagian mahasiswa menjawab dengan pilihan jawaban b dengan persentase $42,2 \%$, mereka beralasan bahwa gaya tekanan ke alas bejana sama dengan berat zat cair apapun bentuk dasar bejana. Alasan yang disampaikan oleh mahasiswa pada pilihan jawaban b kurang tepat. Sedangkan untuk alasan yang dikemukakan mahasiswa untuk jawaban c juga kurang tepat dikarenakan mahasiswa beranggapan bahwa dengan bentuk bejana yang memiliki lebar yang semakin ke atas semakin lebar mempengaruhi gaya tekan pada alas bejana serta mahasiswa juga beranggapan bahwa semakin ke dalam tekanan di dalam air akan semakin besar, padahal yang ditanyakan adalah gaya tekan pada alas bejana. Mahasiswa yang menjawab dengan jawaban c dan memiliki alasan yang sama dengan persentase $45,8 \%$.

\section{Soal nomor 5}

Pada soal penguasaan konsep yang kedua mengenai prinsip tekanan hidrostatis dengan fluida yang berbeda. Adapun soalnya ditunjukkan pada Gambar 3. Persentase jawaban mahasiswa dan alasan yang dikemukakan mahasiswa pada soal nomor 5 ditunjukkan pada Tabel 3 .

Tabel 3: Persentase jawaban mahasiswa pada soal nomor 5

\begin{tabular}{|l|c|}
\hline \multicolumn{1}{|c|}{ Pilihan jawaban } & Persentase \\
\hline a. (1) & $31,1 \%$ \\
\hline b. (2) & $12 \%$ \\
\hline c. (3) & $7,3 \%$ \\
\hline d. (4) & $30,3 \%$ \\
\hline e. (1), (2), (3), dan (4) & $19,3 \%$ \\
\hline
\end{tabular}

Berikut adalah analisis hasil jawaban soal penguasaan konsep kedua pada soal nomor 5 . 
Perhatikan pasangan titik-titik yang dihubungkan oleh garis mendatar 1 sampai 4 pada gambar di samping. Pasangan titik yang memiliki tekanan yang sama besar adalah pasangan titik yang dihubungkan oleh garis......

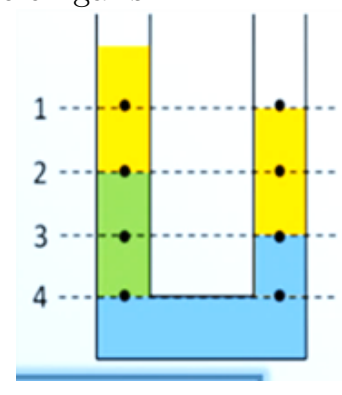

Gambar 3: Gambar soal konsep nomor 5

Pilihan jawaban yang benar adalah d dengan persentase jawaban 30,3\% dengan alasan yang dikemukakan mahasiswa adalah beranggapan bahwa fluida yang menekannya sama dibagian bawahnya, yang dimaksud disini adalah fluidanya berhubungan, serta ada mahasiswa yang asal menebak saja dengan alasan yang kurang tepat, namun jawaban benar. Pada pilihan jawaban yang kurang tepat, khususnya pada jawaban a kebanyakan mahasiswa mengabaikan keadaan fluida yang terpisah, sehingga mereka beranggapan bahwa pilihan jawaban a benar dan sebagian hanya asal menebak saja melalui prinsip yang mereka ingat bahwasanya objek yang sejajar dengan fluida yang sama memiliki tekanan yang sama, padahal yang juga perlu diperhatikan adalah fluida tersebut harus terhubung. Sedangkan pada pilihan jawaban $\mathrm{b}$ dan $\mathrm{c}$ mahasiswa kebanyakan tidak memperhatikan bahwa fluida harus berada digaris sama dengan keadaan fluida yang sama pula. Sedangkan untuk pilihan jawaban e mahasiswa beranggapan bahwa semua pilihan jawaban benar semua dikarenakan berada pada garis yang sejajar, mereka mengabaikan keadaan fluida yang tidak terhubung dan letak objek pada fluida yang tidak sama.

\section{Soal nomor 7}

Pada soal penguasaan konsep yang ketiga mengenai prinsip tekanan hidrostatis dengan fluida yang berbeda yang memiliki densitas yang berbeda. Adapun soalnya ditunjukkan pada Gambar 4. Persentase jawaban mahasiswa dan alasan yang dikemukakan mahasiswa pada soal nomor 7 ditunjukkan pada Tabel 4 .

Berikut akan dibahas mengenai analisis pada soal nomor 7 , mahasiswa dapat menjawab dengan alasan yang tepat dengan persentase $22 \%$. Sedangkan untuk
Cairan kuning dan biru dicampur lalu diaduk hingga merata kemudian dituangkan ke dalam pipa U. Jika densitas cairan kuning lebih kecil daripada cairan biru, maka formasi kedua cairan tersebut dalam pipa $U$ yang mungkin terjadi saat setimbang adalah......

Gambar 4: Gambar soal konsep nomor 7

Tabel 4: Persentase jawaban mahasiswa pada soal nomor 7

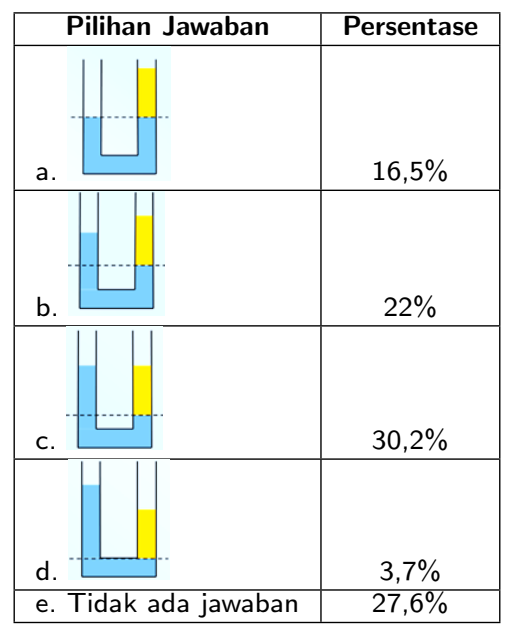

jawaban yang salah mahasiswa paling banyak memilih pilihan jawaban c dengan pesentase $30,2 \%$, mereka beranggapan bahwa dengan memiliki garis yang sejajar, maka ketinggian fluida akan sejajar juga, hal ini bisa saja terjadi jika $\rho_{\text {biru }}=\rho_{\text {kuning }}$. Mahasiswa masih bingung untuk menngaplikasikan formula tekanan hidrostatis $p_{h}=p_{0}+\rho g h$ dengan benar, hal ini juga yang menyebabkan mahasiswa dengan persentase $27,6 \%$ tidak menjawab soal nomor 7 tersebut.

\section{Soal nomor 10}

Pada soal penguasaan konsep yang keempat ini membahas mengenai persamaan tekanan hidrostatis apabila dipengaruhi oleh tekanan atmosfer. Adapun soalnya ditunjukkan pada Gambar 5. Persentase jawaban mahasiswa dan alasan yang dikemukakan mahasiswa pada soal nomor 10 ditunjukkan pada Tabel 5.

Tabel 5: Persentase jawaban mahasiswa pada soal nomor 10

\begin{tabular}{|l|c|}
\hline Pilihan Jawaban & Persentase \\
\hline BENAR & $28,4 \%$ \\
\hline SALAH & $40,4 \%$ \\
\hline KOSONG & $31,2 \%$ \\
\hline
\end{tabular}


Gambar di bawah ini merupakan gambar barometer. Pilihlah BENAR atau SALAH pada pernyataan berikut ini, $p_{a t m}=\rho g h$.

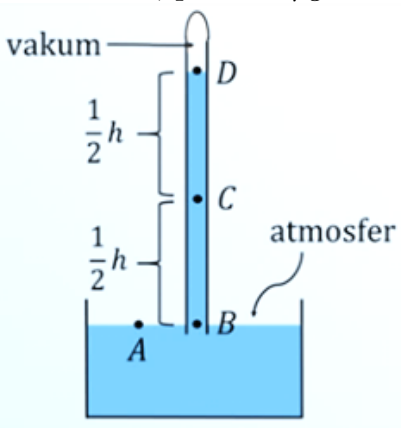

Gambar 5: Gambar soal konsep nomor 10

Berikut akan dibahas mengenai analisis kesalahan pada soal nomor 10. Pada hasil data yang diperoleh terdapat $71,6 \%$ mahasiswa yang menjawab soal nomor 10 kurang tepat, kebanyakan mahasiswa kebingungan untuk mengaplikasikan formula tekanan hidrostatis. pada penelitian ini ditemukan alasan mahasiswa menganggap pernyataan tersebuut salah dikarenakan menurut analisa mereka $p_{a t m}=p_{D}+\rho g h$ sesuai dengan formula tekanan hidrostatis, namun perhatikan kembali bagian atas pipa tersebut tidak terdapat udara yang berarti vakum, artinya $p_{D}=$ 0 , sehingga $p_{a t m}=\rho g h$ pernyataan tersebut adalah pernyataan yang benar dengan persentase jawaban mahasiswa yang didapat adalah sebesar $28,4 \%$ dengan mengemukakan alasan yang tepat.

\section{Soal nomor 13}

Pada soal penguasaan konsep yang kelima ini membahas mengenai persamaan tekanan hidrostatis apabila dipengaruhi oleh tekanan atmosfer. Adapun soalnya ditunjukkan pada Gambar 6. Persentase jawaban mahasiswa dan alasan yang dikemukakan mahasiswa pada soal nomor 13 ditunjukkan pada Tabel 6.

Tabel 6: Persentase jawaban mahasiswa pada soal nomor 13

\begin{tabular}{|l|c|}
\hline Pilihan Jawaban & Persentase \\
\hline BENAR & $21,1 \%$ \\
\hline SALAH & $73,4 \%$ \\
\hline KOSONG & $5,5 \%$ \\
\hline
\end{tabular}

Berikut akan dibahas mengenai analisis kesalahan pada soal nomor 13. Pada hasil data yang diperoleh terdapat 78,9\% mahasiswa yang menjawab soal nomor 13 kurang tepat, kebanyakan mahasiswa menganggap bahwa tekanan pada titik A, B, dan C tidak sama
Perhatikan gambar berikut. Catatan: gaya elastis tutup corong diabaikan terhadap gaya-gaya oleh tekanan udara maupun cairan. Pilihlah BENAR atau SALAH pada pernyataan berikut ini, $p_{A}=$ $p_{B}=p_{C}$.

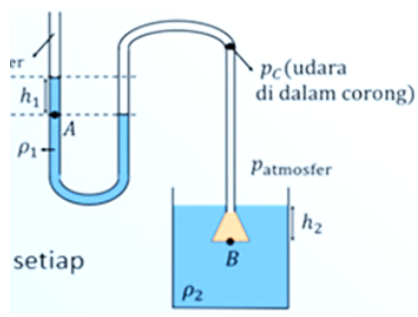

Gambar 6: Gambar soal konsep nomor 13

dikarenakan letak objek yang tidak segaris dengan permukaan bumi, padahal udara yang di dalam selanng tidak dapat diabaikan, dengan adanya udara tersebut tekanan di dalam selang sama di semua titik. Jadi tekanan udara di dalam selang pada semua titik memiliki tekanan yang sama. Berdasarkan persamaan umum tekanan hidrostatis, yakni $p_{h}=p_{0}+\rho g h$ maka $p_{A}=p_{D}$ sedangkan $p_{D}=p_{E}$ karena tekanan udara di dalam selang sama di semua titik maka $p_{E}=p_{F}$ dan juga $p_{B}=p_{F}$, sehingga $p_{A}=p_{D}=p_{E}=p_{F}=p_{B}$ dengan demikian $p_{A}=p_{B}=p_{C}$, mahasiswa yang dapat menjelaskan hal tersebut dengan tepat sebanyak $21,1 \%$.

Analisis keseluruhan dapat dinyatakan bahwa mahasiswa belum dengan tepat mengaplikasikan persamaan tekanan hidrostatis, kebanyakan mahasiswa masih kebingungan mengaplikasikannya pada keadaan vakum dan berudara. Mahasiswa juga hanya mengingat prinsip dasar saja yaitu ketika objek berada di dalam fluida dengan ke dalaman yang sama maka memiliki tekanan yang sama, disini mahasiswa tidak memperhatikan jenis fluida yang digunakan, keadaan fluida yang digunakan, dan juga mahasiswa berasumsi semakin dalam dan sempit keadaan di sutau bejana maka akan semakin besar pula tekanan yang mengenai alasnya. Sedangkan untuk soal-soal hukum pascal mahasiswa telah banyak memahami konsep yang berlaku.

\section{KESIMPULAN}

Secara umum kesulitan mahasiswa dalam menyelesaikan soal-soal penguasaan konsep pada materi tekanan hidrostatis dan hukum pascal terletak pada penguasaan konsep persamaan tekanan hidrostatis dan prinsip-prinsip yang bekerja pada tekanan hidrostatis. Di samping itu terdapat mahasiswa juga kesulitan dalam 
menentukan gaya tekan yang bekerja pada alas bejana. Untuk penguasaan konsep hukum pascal mahasiswa telah mampu menjawab dengan benar soal-soal tersebut. Penelitian ini diharapkan untuk membantu para peneliti lainnya dalam mencari solusi untuk meningkatkan penguasaan konsep pada materi hukum pascal dan tekanan hidrostatis.

\section{PENULIS}

1 S. Indana Zulfa

Dari :

(1) Jurusan Fisika, Fakultas Matematika dan Ilmu Pengetahuan Alam, Universitas Negeri Malang

2 Ainun Nikmah

Dari :

(1) Jurusan Fisika, Fakultas Matematika dan Ilmu Pengetahuan Alam, Universitas Negeri Malang

3 E. Khoirun Nisak

Dari :

(2) Departemen Fisika, Fakultas Sains dan Teknologi, Universitas Airlangga

Pustaka

1. Pateda AB, Kendek Y, Saehana S. Analisis Pemahaman Konsep Magnet Mahasiswa Calon Guru Fisika. JPFT (Jurnal Pendidikan Fisika Tadulako Online). 2015;3(2):13-17.

2. Amnirullah L. Analisis Kesulitan Penguasaan Konsep Mahasiswa pada Topik Rotasi Benda Tegar Dan Momentum Sudut (halaman 34 sd 37). Jurnal Fisika Indonesia. 2015;19(56).

3. AI Mubarokah NH. IDENTIFIKASI PEMAHAMAN KONSEP SISWA SMA MATERI FLUIDA STATIS DENGAN MENGGUNAKAN CR (Certainty of Response Index). COMPTON: Jurnal Ilmiah Pendidikan Fisika. 2019;6(1):1-7.

4. Purwanto MG, Nurliani R, Kaniawati I, Samsudin A. Promoting the hydrostatic conceptual change test (HCCT) with four-tier diagnostic test item. In: Journal of Physics: Conference Series. vol. 1013. IOP Publishing; 2018. p. 12035

5. Wijaya CP, Handayanto SK, Muhardjito M. The diagnosis of senior high school class $\times$ mia b students misconceptions about hydrostatic pressure concept using three-tier. Jurnal Pendidikan IPA Indonesia. 2016;5(1):13-21.

6. Serway RA, Jewett JW. Physics for scientists and engineers with modern physics. Cengage learning; 2018.

7. Knight RD. Physics for scientists and engineers. Pearson Higher Ed.; 2017.

8. Young HD, Freedman RA. University Physics with Modern Physics and MasteringPhysics. Academic Imports Sweden AB; 2015.

9. Widodo L, Yuliati L, Parno P. Eksplorasi Penguasaan Konsep Awal Siswa pada Materi Fluida Statis. In: Seminar Nasional Pendidikan IPA 2017. vol. 2; 2018.

10. Prastiwi VD, Parno P, Wisodo H. Identifikasi pemahaman konsep dan penalaran ilmiah siswa SMA pada materi fluida statis. Momentum: Physics Education Journal. 2018;

11. Zukhruf KD, Khaldun I, Ilyas S. Remediasi Miskonsepsi Dengan Menggunakan Media Pembelajaran Interaktif Pada Materi Fluida Statis. Jurnal Pendidikan Sains Indonesia (Indonesian Journal of Science Education). 2016;4(1).

12. Zukhruf K. Mengidentifikasi Miskonsepsi Fluida Statis pada Mahasiswa Calon Guru Fisika Universitas samudra. Jurnal Pendidikan Fisika dan Sains. 2018;1(02):11-16.
13. Pebriana I. Program Resitasi berbantuan Komputer untuk Meningkatkan Pemahaman Konsep Mahasiswa pada Topik Mekanika Fluida. DISERTASI dan TESIS Program Pascasarjana UM. 2018;. 